\title{
Characterization of Soil Profile at Siddharthanagar Municipality Bhairahawa, Nepal
}

\author{
Srijana Bhattarai ${ }^{1 *}$, Sujan Thapa ${ }^{1}$, Sristi Khanal ${ }^{1}$, Sarad Giri ${ }^{1}$, Bibek Gyawali ${ }^{1}$, Janma Jaya Gairhe ${ }^{2}$, Suresh \\ Simkhada ${ }^{3}$
}

${ }^{1}$ Tribhuwan University, Institute of Agriculture and Animal Science, Paklihawa, Nepal

${ }^{2}$ Tribhuwan University, Gauradaha Campus, Jhapa, Nepal

${ }^{3}$ Agriculture and Forestry University, Rampur, Nepal

*Corresponding Author: Srijana Bhattarai, Tribhuwan University, Institute of Agriculture and Animal Science, Paklihawa, Nepal.

Received: July 16, 2019; Published: August 16, 2019

DOI: 10.31080/ASAG.2019.03.0615

\begin{abstract}
To investigate the physical and chemical properties of soils around Siddharthanagar, research on soil profile characterization at and around Siddharthanagar, Bhairahawa, Nepal was conducted from 10th February and concluded on 5th April 2018. The sample was taken from 30 cultivated and 30 uncultivated sites by digging the pits up to $65 \mathrm{~cm}$ deep and $1 \mathrm{~m}$ wide. Each pit were analyzed for horizon distinction, depth of horizons, diagnostic horizon, boundaries, soil consistency, color, mottling and soil texture through field observation and nitrogen, phosphorous, potassium, pH and organic matter content in soil by laboratory analysis. The study revealed that most of the soils were dominated with diagnostic ochric surface horizon and cambic subsurface horizons with wavy horizon boundary. Clay loam has dominated the texture of most sites with horizon A dominated by iron mottles. Most dominating surface soil color was yellowish brown and with yellow subsurface horizon. Particle density of both horizons were more in uncultivated land and bulk density of surface horizon was more in cultivated land than that of uncultivated land. The nitrogen and phosphorous levels was found to be very high in both sub soil and surface soils of both cultivated and uncultivated soils, whereas potassium levels was relatively high on both conditions. The organic matter was found to be high in surface soils of both cultivated and uncultivated soils and was medium in sub soils of both land use practices, whereas PH was slightly basic at both land use systems requiring no reclamation measures. Findings on the physical and chemical properties of soil from the soil profile assessment will aid the farmer in planting their crops according to the nutrient status and condition of soil and obtain better results, being more precise in agriculture.
\end{abstract}

Keywords: Soil Profile; Characterization; Physical Properties; Chemical Properties

\section{Introduction}

Soil profile is defined as the vertical section exposing a set of horizons in the wall of the pit dug $1 \mathrm{~m}$ deep and about a meter wide [1]. Soil profile descriptions are basic data in all soil surveys which provide major part of the information required for correlation and classification of the soils of an area and are essential for interpreting soils and for coordinating interpretations between soil survey areas. They also provides information for the evaluation of environmental and economic effects of proposed land uses through groupings or ratings of soils according to their limitations, suitability, and potentials for specified uses [2].

Very little have been accessed about the quality of soil in Nepal. Somewhere attempts are made but still they are not including all of the soil properties [3]. The specific soil problems and threat to Nepal are decline in soil productivity, Organic matter, nutrient loss, landslide, pollution, flooding and surface sealing. [4]. Soil profile characterization by the soil scientists can provide the provision for the soil information systems and management models at appropriate scales, and the development of site specific farming systems in the future (White, 1997). The properties of soil vary from place to place with variation not being random. Wherever all elements of the five factors are the same, soils are the same for most of the part. Soils are similar under similar environments in different places. This regularity permits prediction of the location of many different kinds of soil. This fundamental principle makes soil survey practical [5]. The primary focus of farmers, land managers and policy makers of Nepal has been that of enhancing agricultural production, hence requiring emphasis on the soil fertility, monitoring and augmentation, and erosion control [3]. The key physiochemical and biological parameters of soil should be monitored extensively and systematically that would serve as reliable soil quality indices which is need of Nepal and Himalayan region [3]. From the onset of surveys, to determine distribution and extent of soil, characteristics and kinds of soils have had to be identified. The soil surveys 
thus generated progressively more knowledge [6]. The main purpose behind the study of soil at and around IAAS, Paklihawa is to access soil profile at and around IAAS, Paklihawa, Rupandehi with objectives of exploring the Physical and Chemical properties and determining the condition of soil to support plant growth.

\section{Materials and Method}

The materials used and methods adopted during the course of experimentation are described in the chapter under following headings.

\section{Description of the experimental site}

The survey on "Soil Profile Characterization" was carried out at and around IAAS farm of Paklihawa at different sites as Paklihawa, Durgamandir, Ranigaun, Sitapath, UCMS, Meudihawa, Jhandibazzar, Jogikuti, Nuidihawa, Belhaiya, Magartol, Panchabatika, Jungle tol, Chamar tol and fulpur of Siddharthanagar Municipality.Siddharthanagar municipality lies $110 \mathrm{~m}$ above sea level located at the latitude of $27^{\circ} 30^{\prime} 0$ North and longitude of $83^{\circ} 27^{\prime} 0$ East having 2965 ha agricultural land out of total 36.03 sq.km. The maximum and minimum temperature of the area is $2.4^{\circ} \mathrm{C}$ and $45.2^{\circ} \mathrm{C}$ respectively with average rainfall of $1436.5 \mathrm{~mm}$. (MOFALD, Siddharthanagar municipality).

\section{Field study}

Field study was started on $10^{\text {th }} \mathrm{Feb}$ and completed at $21^{\text {st }} \mathrm{Feb}$ 2018. A survey form was developed for analysis of soil properties which were evident in the field. 60 pits were dug out at and around IAAS farm for soil profile characterization. Among them 30 pits were from cultivated (wheat at tillering phase) and 30 pits were from uncultivated land through random selection at ward no 1 and 2. Each pit were analyzed for parent material, drainage class, depth of ground water, horizon distinction, depth of horizons, diagnostic horizon, boundaries, soil consistency, color, mottling, soil texture and porosity through field observation. Soil color was determined by using Munsell color chart and feel and appearance method for texture and resistance to rupture in hand (dry, moist, wet) for consistency of soil and horizon boundary was determined by using figure as reference.

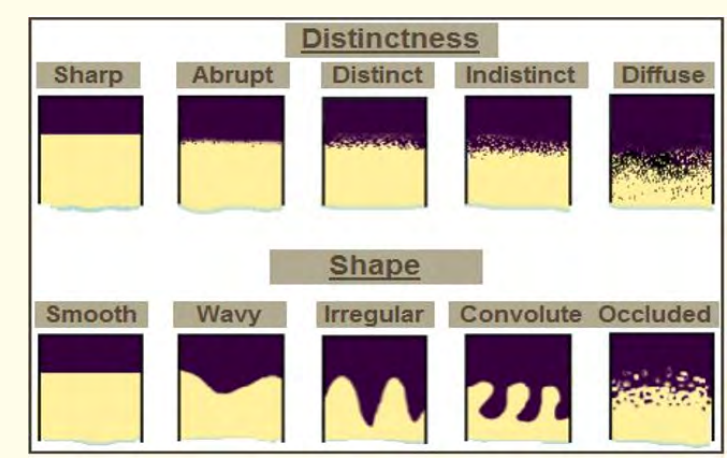

Figure 1: Horizon boundary showing distinctness and shape. (Source: NZ soils).

\begin{tabular}{|l|c|c|c|}
\hline $\begin{array}{c}\text { Mottle } \\
\text { size }\end{array}$ & Criteria(mm) & $\begin{array}{c}\text { Mottle } \\
\text { quantity }\end{array}$ & $\begin{array}{c}\text { Criteria } \\
\text { (\% of surface area) }\end{array}$ \\
\hline Fine & $<5$ & Few & $<2 \%$ \\
\hline Medium & $5-15$ & Common & $2-20 \%$ \\
\hline Coarse & $>15$ & Many & $20 \%$ \\
\hline
\end{tabular}

Table 1: Mottling determination.

Source: Land Resource Mapping Project, 2071

\section{Sample collection}

Soil samples of two horizons (A and B) from each pits were collected for chemical (N2, P205, K20) and physical (particle density, $\mathrm{pH}$, Organic matter) analysis. For bulk density, soil samples of upper $0-30 \mathrm{~cm}$ of each pit were collected by using core sampler with ring. Therefore 3 samples from each pits, altogether 180 samples were collected.

\section{Laboratory analysis}

Laboratory analysis was started on $24^{\text {th }}$ Feb and completed on $5^{\text {th }}$ April 2018. The collected soil samples were chemically and physically analyzed to determine $\mathrm{N}_{2}, \mathrm{P}_{2} \mathrm{O}_{5}$ and $\mathrm{K}_{2} \mathrm{O}, \mathrm{pH}$, Organic matter in the laboratory of NWRP, National Wheat Research Programmee, Bhairahawa and rated by using rating chart.

\begin{tabular}{|l|c|c|c|c|}
\hline $\begin{array}{c}\text { Nutrient } \\
\text { status }\end{array}$ & $\begin{array}{c}\text { Soil organic } \\
\text { matter (\%) }\end{array}$ & $\begin{array}{c}\text { Total N } \\
\mathbf{( \% )}\end{array}$ & $\begin{array}{c}\text { Available } \\
\mathbf{P}_{\mathbf{2}} \mathbf{O}_{\mathbf{5}} \mathbf{( k g} \\
\mathbf{h a}^{-1} \mathbf{)}\end{array}$ & $\begin{array}{c}\text { Available } \\
\mathbf{K}_{\mathbf{2}} \mathbf{\mathbf { O }} \mathbf{( k g} \\
\mathbf{h a}^{-1} \mathbf{)}\end{array}$ \\
\hline Very low & $<0.75$ & $<0.03$ & $<10$ & $<55$ \\
\hline Low & $0.75-1.5$ & $0.03-0.07$ & $10-30$ & $55-110$ \\
\hline Medium & $1.5-3$ & $0.07-0.15$ & $30-55$ & $110-280$ \\
\hline High & $3-5$ & $0.15-0.25$ & $55-110$ & $280-500$ \\
\hline Very high & $>5$ & $>0.25$ & $>110$ & $>500$ \\
\hline
\end{tabular}

Table 2: Rating chart for soil fertility status of soil. Source: Soil Science Division, Bhairahawa, NWRP, Nepal.

\begin{tabular}{|l|c|}
\hline Soil Ph & Soil reaction \\
\hline$<5$ & Strongly acidic \\
\hline $5-6.5$ & Moderately acidic \\
\hline 7 & Neutral \\
\hline$>7$ & Alkaline \\
\hline
\end{tabular}

Table 3: Rating chart for soil $\mathrm{pH}$. Source: (Brady, 2002)

For measurement of Bulk density and Particle density soil samples of core sampler was oven dried on hot air oven at $105^{\circ} \mathrm{c}$ in the Soil laboratory of Institute of Agriculture and Animal Science.

\section{Data analysis}

The data obtained from the field survey and laboratory analysis was entered into MS-Excel and statistical analysis was done by us- 
ing Statistical Package for Social Science (SPSS 23). Both descriptive and analytical method were used to analyze the data. MS- Excel (Excel 2013) was used for making charts and graphs.

\section{Results and Discussion}

Diagnostic horizons

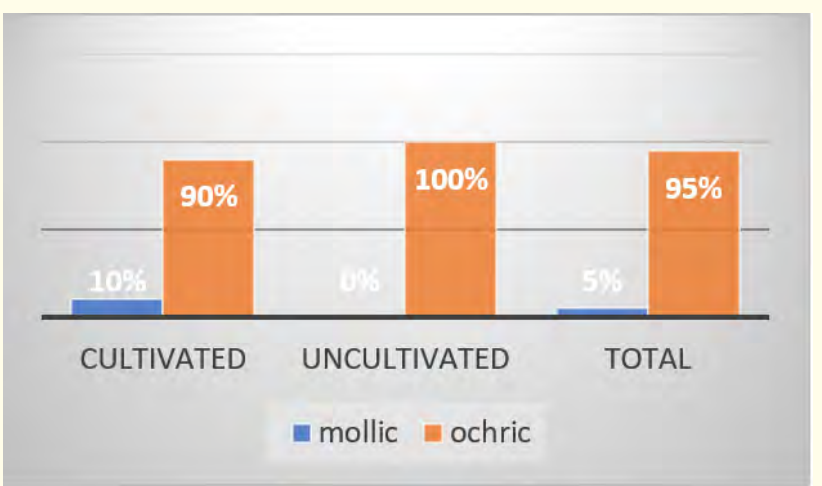

Figure 2: Diagnostic A horizon.

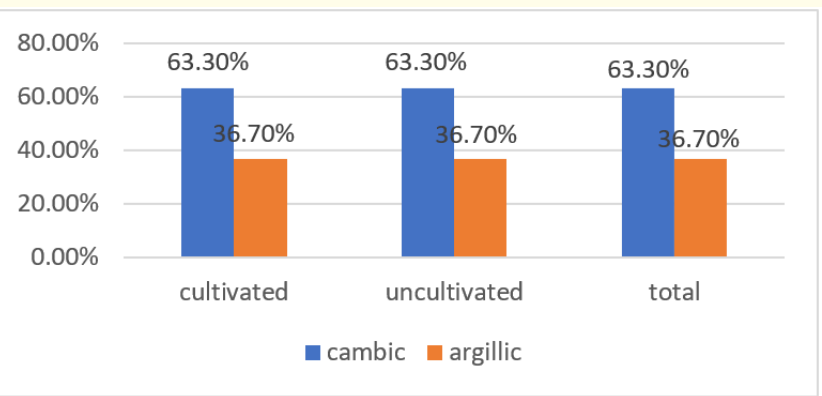

Figure 3: Diagnostic B horizon.

In A horizon, Out of total site, $95 \%$ of had ochric horizon whereas only $5 \%$ had mollic horizon. In cultivated land $10 \%$ had mollic horizon whereas $100 \%$ of uncultivated land had ochric horizon. As $\chi^{2}=0.076, P>0.05$ ), the value is not significant. So, land use system didn't affect diagnostic horizon whereas in B horizon out of the total sites $63.30 \%$ had cambic soils and $36.70 \%$ had argillic soils. Both cultivated land and uncultivated lands had $63.30 \%$ cambic soil. As $\chi^{2}=1, p>0.5$, the value is not significant. So, land use system didn't affect diagnostic horizon.

Horizon boundary

\begin{tabular}{|l|c|c|c|}
\hline \multirow{2}{*}{} & \multicolumn{2}{|c|}{ Land Use system } & \multirow{2}{*}{ Total } \\
\cline { 2 - 3 } & Cultivated & Uncultivated & \\
\hline Sharp & $3.3 \%$ & $0.0 \%$ & $1.7 \%$ \\
\hline Abrupt & $3.3 \%$ & $0.0 \%$ & $1.7 \%$ \\
\hline Distinct & $80.0 \%$ & $83.3 \%$ & $81.7 \%$ \\
\hline Indistinct & $13.3 \%$ & $16.7 \%$ & $15.0 \%$ \\
\hline
\end{tabular}

Table 4: Distinctness in horizon boundary.
80\% cultivated land and $83.3 \%$ uncultivated land have distinct horizon boundary.

Shape

\begin{tabular}{|l|c|c|c|}
\hline $\begin{array}{c}\text { Horizon } \\
\text { boundary }\end{array}$ & $\begin{array}{c}\text { Cultivated } \\
\text { (\%) }\end{array}$ & $\begin{array}{c}\text { Uncultivated } \\
\text { (\%) }\end{array}$ & $\begin{array}{c}\text { Total } \\
\text { (\%) }\end{array}$ \\
\hline Smooth & 20 & 10 & 15 \\
\hline Wavy & 60 & 50 & 55 \\
\hline Irregular & 20 & 40 & 30 \\
\hline
\end{tabular}

Table 5: Horizon boundary shape.

$60 \%$ of cultivated land had wavy boundary and $20 \%$ each have smooth and irregular boundary. Whereas 50\% of uncultivated land have wavy boundary and $40 \%$ have irregular boundary. As $\chi^{2}=0.195, p>0.05$, the value is not significant. So, land use system did not affect horizon boundary.

\section{Consistency}

All of the soil of horizon A and B had plastic wet consistency. Both cultivated and uncultivated soils have $90 \%$ loose consistency. Most of the soils had friable moist consistency in both land use system in horizon A. Most of the soils had loose dry consistency in both land use system of horizon B and Most of the soils of horizon $B$ had friable moist consistency.

Texture

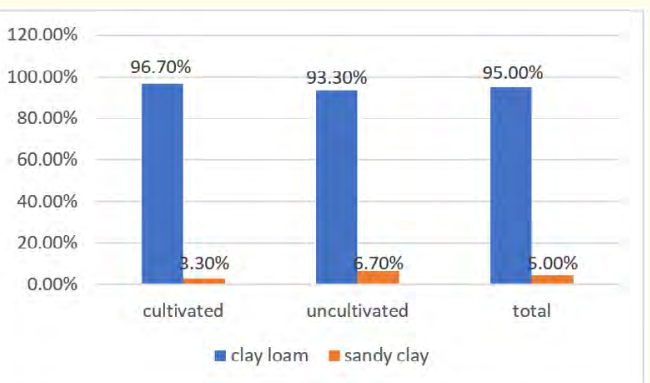

Figure 4: Bar graph showing soil texture of Horizon A.

The soil texture of the horizon A of cultivated land and uncultivated land was not significantly different $\left(x^{2}=0.554, \mathrm{P}>0.05\right)$. Soil texture of $95 \%$ of total site was clay loam, whereas $5 \%$ was sandy clay.

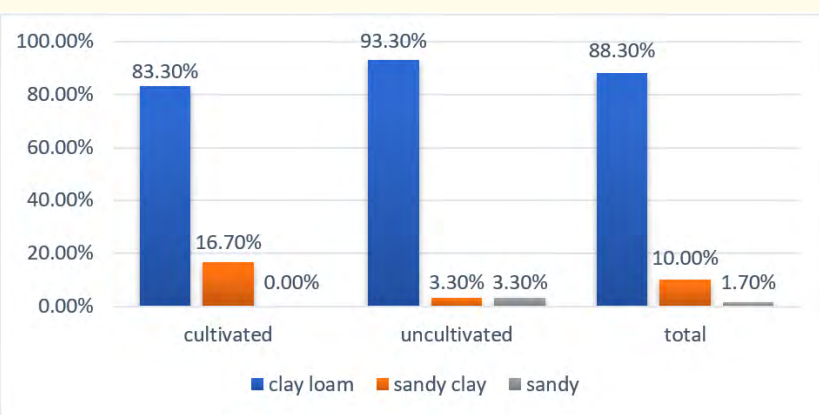

Figure 5: Soil texture of Horizon B of cultivated and uncultivated land. 
The soil texture of the horizon B of cultivated land and uncultivated land was not significantly different $\left(x_{2}=0.147, \mathrm{P}>0.05\right)$. Soil texture of $93.3 \%$ of uncultivated land was dominated with clay loam, $3.30 \%$ was sandy clay and $3.30 \%$ of sand was only found on uncultivated land.

\section{Soil color}

The soil color of different land use system was not significantly different. $\left(x^{2}=0.477, P>0.05\right)$. Most of the soil, $25 \%$ of total site, $30 \%$ of cultivated land and $20 \%$ of uncultivated land was of yellowish brown color. The soil color of different land use system was not significantly different. $(x 2=0.480, P>0.05) .33 .3 \%$ of total site, $26.7 \%$ of cultivated land and $36.7 \%$ of uncultivated land was of yellow color.

The color of the soil sample should be determined in uniform, bright light, preferably sunlight, and report the closest match from Munsell chart as it is impossible to obtain the exact match of soil color to color chip. [7]. Various combinations of iron oxides result in brown and yellow-brown colors [8]. Soil tends to be more yellowish brown to red depending upon the hydration of ferric oxide and extensive weathering of soil parent minerals content in moist warm regions which shows effect of temperature and moisture characteristics on soil color [9].

\section{Mottling}

Among the 60 pit samples, 10 pits from uncultivated lands had no mottling.

Mottling of soil in horizon A

\begin{tabular}{|l|c|c|}
\hline $\begin{array}{c}\text { Mottling in soil of } \\
\text { Horizon A }\end{array}$ & $\begin{array}{c}\text { Cultivated land } \\
\text { (\%) }\end{array}$ & $\begin{array}{c}\text { Uncultivated land } \\
\text { (\%) }\end{array}$ \\
\hline $\mathrm{Fe}$ & $76.7(23)$ & $46.7(14)$ \\
\hline $\mathrm{Fe}$ and $\mathrm{Ca}$ & $6.7(2)$ & 0.0 \\
\hline Fe and $\mathrm{Mn}$ & $10.0(3)$ & $13.3(4)$ \\
\hline $\mathrm{Mn}$ and $\mathrm{Ca}$ & 0.0 & $3.3(1)$ \\
\hline $\mathrm{Fe}, \mathrm{Mn}$, and $\mathrm{Ca}$ & $6.7(2)$ & $3.3(1)$ \\
\hline None & 0 & $33.33(10)$ \\
\hline
\end{tabular}

Table 6: Mottling in soil of profile samples in percentage.

The numbers in parentheses represent the number of pit samples.

The distribution pattern of mottles showed maximum of the pits were found to be mottled with $\mathrm{Fe}(61.7 \%)$ and $16.7 \%$ were not mottled at all. Pearson Chi-square value was found to be $0.008(<0.05)$ indicating that the mottling of cultivated land was significantly different from that of uncultivated land. Regarding the mottling, the profiles when examined for mottling in A horizon, were found mottled with Fe, few in quantity, fine in sizes and faint in contrast most dominantly.

\section{Mottling in horizon B}

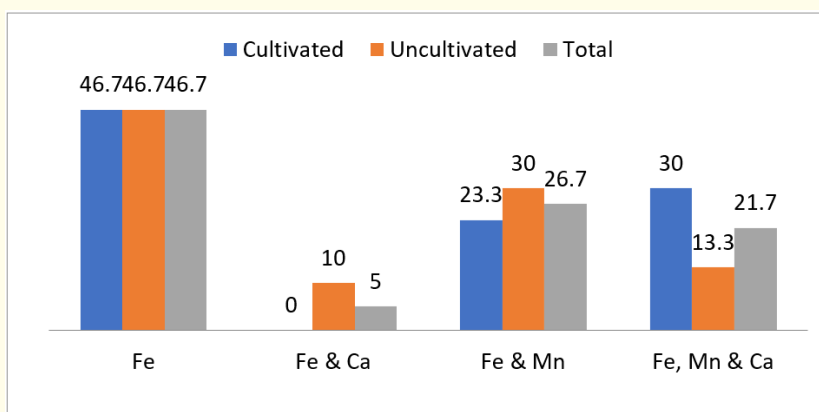

Figure 6: Bar graph representing the mottling of soil in terms of percentage of the cultivated, uncultivated and total sites of Horizon B.

The bar graph represents that the B horizon was found dominant in mottling with Fe in both cultivated and uncultivated land followed by Fe, Mn and Ca cultivated and Fe and Mn in uncultivated land sites. 29 cultivated sites and all uncultivated sites B horizon, examined for mottling were found to have few mottling. The fine mottling's were seen in both cultivated and uncultivated land as dominant, followed by medium and coarse mottling sizes. The mottling quantity in both cultivated and uncultivated land sites were found to be dominantly distinct. The sites when observed for the mottling in horizon B were found to have most dominantly Fe mottling, few in quantity, fine in sizes and distinct in contrast.

\section{Particle and bulk density}

Soil particle density is related to soil porosity, degree of compaction, movement of air and water into and through the soil, ease of root growth as well as other properties [10]. Bulk density is a dynamic property of soil which varies with the soil structural conditions and in general increases with profile depth, due to changes in organic matter content, porosity and compaction [11].

\begin{tabular}{|l|c|c|c|c|c|}
\hline & $\begin{array}{c}\text { land use } \\
\text { system }\end{array}$ & $\mathbf{N}$ & Mean & S. D. & $\begin{array}{c}\text { Std. } \\
\text { Error } \\
\text { Mean }\end{array}$ \\
\hline $\begin{array}{l}\text { Particle } \\
\text { density } \\
\text { of soil of } \\
0-30 \mathrm{~cm}\end{array}$ & Cultivated & 30 & 2.45035 & .179244 & .032725 \\
\cline { 2 - 6 } & Uncultivated & 30 & 2.48337 & .173235 & .031628 \\
\hline $\begin{array}{l}\text { Particle } \\
\text { density of } \\
\text { soil of } \\
30-60 \mathrm{~cm}\end{array}$ & Cultivated & 30 & 2.50489 & .188385 & .034394 \\
\cline { 2 - 6 } & Uncultivated & 30 & 2.53316 & .158883 & .029008 \\
\hline $\begin{array}{l}\text { Bulk } \\
\text { density } \\
\text { of soil of } \\
0-30 \mathrm{~cm}\end{array}$ & Cultivated & 30 & 1.57399 & .169775 & .030997 \\
\cline { 2 - 6 } & Uncultivated & 30 & 1.47436 & .236012 & .043090 \\
\hline
\end{tabular}

Table 7: Particle and bulk density of soil. 
Particle density of soil of both depth $0-30 \mathrm{~cm}$ (2.48337) and 30$60 \mathrm{~cm}$ (2.53316) was more in uncultivated land. The average particle density for mineral soils is usually given as $2.65 \mathrm{~g} / \mathrm{cm}^{3}$ [8]. Bulk density of cultivated land was more (1.57399) than uncultivated land. For organic soil components, the particle density ranges between 1.0 and $1.5 \mathrm{~g} \mathrm{~cm}^{3}$ [12], for most minerals soil ranges from $2.6-2.75 \mathrm{~g} / \mathrm{cm}^{3}$ but up to $3 \mathrm{~g} / \mathrm{cm}^{3}$ for high dense minerals [13].

Organic matter and pH

\begin{tabular}{|l|c|c|c|c|c|}
\hline & $\begin{array}{l}\text { land use } \\
\text { system }\end{array}$ & N & Mean & S. D. & $\begin{array}{c}\text { Std. } \\
\text { Error } \\
\text { Mean }\end{array}$ \\
\hline $\begin{array}{l}\text { Organic } \\
\text { matter } \\
\text { content } \\
\text { of soil of } \\
\text { horizon A }\end{array}$ & Cultivated & 30 & 4.25673 & 2.461720 & .449447 \\
\cline { 2 - 6 } & Uncultivated & 30 & 3.33147 & 2.198516 & .401392 \\
\hline $\begin{array}{l}\text { Organic } \\
\text { matter } \\
\text { content } \\
\text { of soil of } \\
\text { horizon B }\end{array}$ & Cultivated & 30 & 2.60407 & 1.814147 & .331216 \\
\cline { 2 - 6 } $\begin{array}{l}\text { pH con- } \\
\text { tent of } \\
\text { the soil of } \\
\text { horizon A }\end{array}$ & Uncultivated & 30 & 2.35840 & 2.016796 & .368215 \\
\cline { 2 - 6 } & Uncultivated & 30 & 7.2547 & .79584 & .14530 \\
\hline $\begin{array}{l}\text { pH con- } \\
\text { tent of } \\
\text { the soil of } \\
\text { horizon B }\end{array}$ & Cultivated & 30 & 7.5803 & .59222 & .10812 \\
\cline { 2 - 6 } & Uncultivated & 30 & 7.4460 & .70172 & .12812 \\
\hline
\end{tabular}

Table 8: $\mathrm{pH}$ and organic matter according to land use system and horizons.

The organic matter content of both the cultivated and uncultivated land was high in horizon $A$ whereas medium in horizon $B$ of both land use system. The $\mathrm{pH}$ content of both horizons of both land use system was slightly basic. It is essential for periodic checking of soil $\mathrm{pH}$ and acidic $\mathrm{pH}$ can be controlled by adding ground lime- stone whereas ammonium nitrate, Urea, ammonium Sulphate can be used for maintaining highly basic soils [14]. The value of organic matter and $\mathrm{pH}$ content was not significant. The organic matter content was more in cultivated land in both horizons than uncultivated land decreasing with depth. Surface soils are composed of approximately 1 to $6 \%$ organic matter, with SOM decreasing with depth [1]. The pH of upper horizons was lower than lower horizons in both land use system. This might be due to oxidation of nitrogen fertilizer applied to soil, decomposition of leaf litter [13]. SOM help to buffer soils to maintain a pH range optimal for plant growth [15] i.e. 6.5- 7.5 [8]. The organic matter content was more in cultivated land in both horizons than uncultivated land decreasing with depth. Surface soils are composed of approximately 1 to $6 \%$ organic matter, with SOM decreasing with depth [1]. The $\mathrm{pH}$ of upper horizons was lower than lower horizons in both land use system. This might be due to oxidation of nitrogen fertilizer applied to soil, decomposition of leaf litter [1]. SOM help to buffer soils to maintain a pH range optimal for plant growth [15] i.e. 6.5- 7.5 [8]

\section{Nutrient content $\left(\mathrm{N}_{2}, \mathrm{P}_{2} \mathrm{O}_{5}, \mathrm{~K}_{2} \mathrm{O}\right)$}

The mechanisms involved in the vertical distribution of the nutrients in the soil includes weathering, leaching and biological cycling process [16]. The proportion of substances from the weathering of parent material increases with depth [17].

The $\mathrm{N}_{2}(\%), \mathrm{P}_{2} \mathrm{O}_{5}(\mathrm{~kg} / \mathrm{ha})$ content in both horizons of both cultivated and uncultivated land was found to be very high whereas $\mathrm{K}_{2} \mathrm{O}(\mathrm{kg} / \mathrm{ha}$ ) was found to be high in both conditions as compared to soil fertility rating chart of NWRP.

The nutrient content was found to be non-significant. $\mathrm{N}_{2}(\%)$ content of uncultivated land was more in both horizon with mean of 0.47 in horizon A and 0.259 in horizon B than cultivated soil $\mathrm{P}_{2} \mathrm{O}_{5}(\mathrm{~kg} / \mathrm{ha})$ content of soil of horizon $\mathrm{A}$ of cultivated land was more than uncultivated (241.388, very high) whereas lower $\mathrm{P}_{2} \mathrm{O}_{5}$ $(\mathrm{kg} / \mathrm{ha})$ content on horizon B of cultivated land than uncultivated

\begin{tabular}{|l|c|c|c|c|c|}
\hline & land use system & $\mathbf{N}$ & Mean & S. D & Std. Error Mean \\
\hline \multirow{2}{*}{$\mathrm{N}_{2}$ content (\%) of soil of horizon A } & Cultivated & 30 & .47483 & .211190 & .038558 \\
\cline { 2 - 6 } & Uncultivated & 30 & .49292 & .280681 & .051245 \\
\hline \multirow{2}{*}{$\mathrm{N}_{2}$ content (\%) of soil of horizon B } & Cultivated & 30 & .20067 & .115419 & .021073 \\
\cline { 2 - 6 } & Uncultivated & 30 & .25958 & .240655 & .043937 \\
\hline \multirow{2}{*}{$\mathrm{P}_{2} \mathrm{O}_{5}(\mathrm{~kg} / \mathrm{ha})$ content of soil of horizon A } & Cultivated & 30 & 255.21291 & 99.199518 & 18.111271 \\
\cline { 2 - 6 } & Uncultivated & 30 & 241.38837 & 116.673512 & 21.301571 \\
\hline \multirow{2}{*}{$\mathrm{P}_{2} \mathrm{O}_{5}(\mathrm{~kg} / \mathrm{ha})$ content of soil of horizon B } & Cultivated & 30 & 194.62539 & 103.732543 & 18.938885 \\
\cline { 2 - 6 } & Uncultivated & 30 & 217.80939 & 109.986967 & 20.080781 \\
\hline \multirow{2}{*}{$\mathrm{K}_{2} \mathrm{O}(\mathrm{kg} / \mathrm{ha})$ content of soil of horizon A } & Cultivated & 30 & 261.91872 & 134.944793 & 24.637436 \\
\cline { 2 - 6 } & Uncultivated & 30 & 269.59744 & 131.218296 & 23.957074 \\
\hline \multirow{2}{*}{$\mathrm{K}_{2} \mathrm{O}(\mathrm{kg} / \mathrm{ha})$ content of soil of horizon B } & Cultivated & 30 & 258.88128 & 112.396364 & 20.520675 \\
\cline { 2 - 6 } & Uncultivated & 30 & 278.66496 & 163.803038 & 29.906206 \\
\hline
\end{tabular}

Table 9: $\mathrm{N}_{2}, \mathrm{P}_{2} \mathrm{O}_{5}, \mathrm{~K}_{2} \mathrm{O}$ content of soil. 
land. (217.81). $\mathrm{K}_{2} \mathrm{O}(\mathrm{kg} / \mathrm{ha}$ ) content of soil of uncultivated land was more on both horizon A (269.59744) and B (278.66496) was more on uncultivated land than cultivated land. Also, we can see that all of the nutrients content are more in A horizon of both land use system than B horizon which might be due to biological cycling of nutrients as biological cycling leads to the increased nutrient concentration at above surface because of aboveground transportation of nutrient by plant roots and are recycled at the soil surface by litter fall [16].

\section{Conclusion}

From the laboratory analysis of the soil it can be concluded, the soils were dominated with diagnostic ochric surface horizon and cambic subsurface horizons. The average depth of A horizon extended from 0-17 cm in most soils. Most of the soils had distinct wavy horizon boundary. Majority of the soils had loose dry consistency and friable wet consistency. Most dominating soil color was yellowish brown on the surface and yellow on the subsurface horizon. Most of the soils in horizon A were dominated by iron mottles, size, contrast and quantity were fine, faint and few respectively. B horizon too had dominating iron mottles and size, contrast and quantity were fine, distinct and many respectively. As the surveyed sites was mostly dominated with clay loamy soil, crops like beans, carrots, beets, swiss chard, rice etc. can be grown suitably to enable farmers to achieve greater economic returns as the soil texture favors cultivation of these crops. Almost all types of crops i.e. bean, broccoli, wheat, maize, radish, gourd etc. are favored by neutral to slightly basic soil PH indicating no requirement of reclamation measures in that area and appreciable amount of gypsum can be added if acidic crops like rice, potato are to be grown. The bulk density of the cultivated land was more than uncultivated land which might be due to compaction caused by high weight machinery such as tractor and combined harvester directing towards the need of minimum tillage practices such as zero tillage system in wheat. Although both land use systems has high amount of nutrients, the results of the study conclude that higher levels of total nitrogen and potassium was found in uncultivated land than cultivated land indicating the maintenance and depleting state of cultivated site from its original stage can be minimized through provision of good crop husbandry practices with addition of organic soil fertilizing source in that area for sustainable crop production.

\section{Acknowledgements}

We would like to express our heartfelt thanks to National Wheat Research Program (NWRP) for providing technical support for conducting this research and Subodh Khanal sir for his guidance during data analysis.

\section{Bibliography}

1. Brady, N.C., \& R.R .Weil. 2002. The Nature and properties of soils, India: Dorling Kindersley,7- 27.

2. Ditzler, C., K. Scheffe, \& C. H. Monger. (Eds.). 2017. Soil survey manual. Soil Science Division Staff. SUSDA. Available from:http://websoilsurvey.nrcs.usda.gov/
3. Bajracharya, R., B. Sitaula, S. Sharma, \& A. Jeng. 2007. Soil quality in the Nepalese context - An analytical review. International Journal of Ecology and Environmental Sciences, 33,143-158

4. Khadka, Y. G. 2015. Soil survey, Soil mapping and Soil status of Nepal, Khumaltar: Nepal Agricultural Research Council.

5. Hudson, B.D. 1992. The soil survey as a paradigm-based science. Soil Science Society of America Journal, 56,836-841.

6. Simonson, W. 1991. The U.S. soil survey-contributions to soil science and its application.

7. Schaetzl, R. J., \& M. L. Thompson. 2015. Soils: Cambridge university press.

8. Foth, H. D. 1978. Fundamentals of soil science. Soil Science, 125(4), 272, 134-147

9. Jobbágy, E. G., \& R. B. Jackson. 2001. The distribution of soil nutrients with depth: global patterns and the imprint of plants. Biogeochemistry, 53(1), 51-77.

10. Bouycous, G. J. 1962. Hydrometer method improved for making particle size analysis of soil. Agron J, 54, 464-465.

11. Chaudhari, P. R.et al. 2013. Soil Bulk Density as related to Soil Texture, Organic Matter Content and available total Nutrients of Coimbatore Soil. International Journal of Scientific and Research Publications, 3(1), 2250-3153.

12. Young, J.L., G. Spycher. 1979. Water-dispersible soil organicmineral particles: I. Carbon and nitrogen distribution. Soil Sci. Soc. Am. J. 43,324-328.

13. Brady, N.C., \& R.R .Weil. 2014. The Nature and properties of soils, India: Dorling Kindersley, 374-417

14. Vossen, P. 2006. Changing pH in soil. University of California Cooperative Extension, (11),1-2.

15. Havlin, J. L. et al. 2005.Soil Fertility and Fertilizers. 7th ed.

16. Trudgill, S.T. 1988. Soil and Vegetation Systems. New York, US: Oxford University Press

17. Kirkby, M. J. 1985. A basis for soil profile modelling in a geomorphic context. European Journal of Soil Science, 36(1), 97121.

Volume 3 Issue 9 September 2019

(C) All rights are reserved by Srijana Bhattarai., et al. 